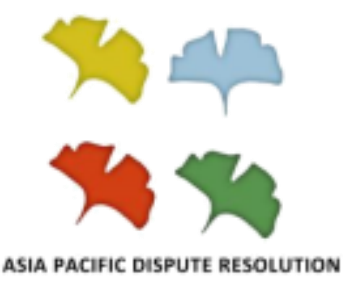

\title{
Labour Arbitration in Mainland China: Its Current State, Characteristics, and Tendencies
}

\author{
Jianyong Li \\ Institute of ADR and Arbitration \\ Shanghai University
}

\section{APDR Working Paper Series Volume 4 Number 1}

ISSN 2371-6304

(c) (i) @ $€$ by Jianyong Li, 2016.

This article is made available as part of the Asia Pacific Dispute Resolution Working Paper Series and is licensed under a Creative Commons Attribution-NonCommercial- 


\title{
LABOUR ARBITRATION IN MAINLAND CHINA: ITS CURRENT STATE, CHARACTERISTICS, AND TENDENCIES ${ }^{1}$
}

\author{
Jianyong Li \\ Institute of ADR and Arbitration \\ Shanghai University
}

\section{The Current Labour Dispute Arbitration System}

As China's market economic reform deepens and workers' legal awareness increases, the economic field faces an increasingly growing number of complicated labour disputes, especially when the labour market opens up, enterprises' labour policy appears more market-oriented, and the labour flows more diversified. In order to better regulate enterprises' labour management system and the labour disputes resolution mechanism, China promulgated a series of laws and regulations. In 2007, China successfully promulgated "Labour Contract Law (LCL)", "Employment Promotion Law of the People's Republic of China (EPLPRC)", "People's Republic of China LDMAL", and other relevant laws and regulations, which greatly improved the labour law system and provided solid legal basis for solving labour disputes. However, from 2008 onwards, the labour disputes started to display complex, multilayered, and paradoxical features. As is evident from the practice of labour disputes arbitration, while China's labour dispute arbitration system functions generally well to solve most kinds of labour disputes, it is still in urgent need for constant updates and improvements, in that part of the provisions lag behind the actual situation, and law implementation is influenced by various external factors.

In contrast to the labour disputes legislations and regulations issued in the past (e.g., the "1993 People's Republic of China Enterprise Labour Disputes Ordinance"), the LDMAL and the "LDMAL Implementation Rules" have been revised and improved in many respects. For example, arbitration awards are final for some labor disputes under certain conditions. Also, the time limitation for the labor arbitration application is extended and the period of time to reach an arbitration reward is shortened, both of which reflect the humanistic tendency in the legislation. However, in terms of law implementation, there are still some defects in China's labour dispute arbitration system, such as the inconsistency of the law application and legal procedure in arbitration and litigation, limited application of labor dispute arbitration rewards as the final decision, the administrative nature of labour arbitration, and an inadequate oversight mechanism for labour arbitration.

\footnotetext{
${ }^{1}$ This paper is part of a larger project entitled "Asia Pacific Dispute Resolution: Understanding Coordinated Compliance with International Trade and Human Rights Standards in Comparative Perspective." The principal Investigator for the project is Dr. Pitman Potter, Professor of Law at the University of British Columbia.
} 


\section{Data Analysis of Labour Dispute Cases}

The data in Table 1 shows that in 2008, the number of labour dispute cases has nearly doubled compared to 2007, leading to a double number of pending cases at the end of 2008compared to 2007. From 2009 to 2012, the number of accepted cases of labour disputes has not increased much, but the total number of accepted cases of labour disputes from 2008 to 2009 is still very high.

Table 1. 2007-2012 Labour Dispute Cases Accepted in China (Unit: case number)²

\begin{tabular}{|c|c|c|c|c|c|c|c|}
\hline \multicolumn{2}{|l|}{ ItemlYear } & 2007 & 2008 & 2009 & 2010 & 2011 & 2012 \\
\hline \multicolumn{2}{|c|}{$\begin{array}{l}\text { Number of cases accepted } \\
\text { in this period }\end{array}$} & 350182 & 693465 & 684379 & 060865 & 589244 & 641202 \\
\hline \multicolumn{2}{|c|}{$\begin{array}{l}\text { Number of pending cases } \\
\text { from the previous period }\end{array}$} & 25424 & 33084 & 83709 & 77926 & 42308 & 36151 \\
\hline \multicolumn{2}{|c|}{$\begin{array}{l}\text { Number of cases settled in } \\
\text { this period }\end{array}$} & 340030 & 622719 & 689714 & 634041 & 592823 & 643292 \\
\hline \multirow{3}{*}{$\begin{array}{l}\text { Means of } \\
\text { settlement }\end{array}$} & $\begin{array}{l}\text { Arbitration } \\
\text { mediation }\end{array}$ & 119436 & 221284 & 251463 & 250131 & 278873 & 302552 \\
\hline & Arbitral award & 149013 & 274543 & 290971 & 266506 & 244942 & 268530 \\
\hline & Others & 71581 & 126892 & 147280 & 117404 & 69008 & 72210 \\
\hline
\end{tabular}

There are two reasons for the sharp increase of labour dispute cases in 2008:

Firstly, the promulgation and implementation of the LCL favored the interests of workers and stimulated the workers' awareness to protect their rights; Secondly, the implementation of the LDMAL. In particular, the extension of the time limit for labour arbitration as well as free arbitration fees has motivated a considerable number of potential cases to be submitted. This suggests that the labour dispute arbitration system facilitated the settlement of labour dispute, thus prompted the booming of labour disputes arbitration and finally has resolved part of the intensive labour disputes.

From 2007 to 2010, the ratios of labour dispute cases settled through the labour arbitration system (including arbitration mediation and arbitration awards) and the number of cases settled were as follows, respectively: $78.9 \%, 79.6 \%, 78.5 \%$ and $81.5 \%$. It indicates that the labour arbitration system has played an irreplaceable role in resolving labour disputes, and

\footnotetext{
${ }^{2}$ For data, see Zhang Zhibing ed., China Labour Statistical Yearbook 2011 (Beijing: China Statistics Press, 2012).
} 
thus has reduced the numbers of the unsettled labor dispute filing to courts. But a considerable number of labour dispute cases still have to be resolved through civil litigation.

\section{The Characteristics of China's Current Labour Dispute Arbitration System}

\section{(1) Arbitration as The Pre-Trial Procedure Under Certain Conditions}

The pre-trial arbitration in the labour dispute is stipulated in Article 5 of the LDMAL which provides that where the parties are dissatisfied with the arbitral award, they may initiate a litigation to the people's court unless otherwise provided for in the LDMAL. This regulation augments the hardship of the understaffed court with increasing volume of litigation. With the implementation of the LCL and the LDMAL, an explosive growing number of complex labour dispute cases if going to the courts, will create a huge backlog of cases in the courts and transfer into a number of unresolved social problems, both of which will damage the authority of the law.

Therefore, considering the uniqueness of labour disputes compared to the general civil and commercial cases, making arbitration as the pre-trial procedure under certain conditions will settle some disputes through the mediation and arbitration system before entering the courts, which will reduce the pressure of the courts and solve more labor disputes effectively. Meanwhile, the labor dispute arbitration with the final validity is in line with the tendency to draw a line between the resolution of general civil dispute and labor dispute. Article 47 of the LDMAL provides that an arbitration award on a recovery of labor remuneration, medical expenses on work-related injury, and economic indemnity, or compensation etc., shall be legally effective from the date when it is released. This "One-tier final reward" system has achieved the separation between arbitration and litigation, by making final arbitration rewards to labour disputes cases with small subject value or clear facts on rights and duties.

\section{(2) Tripartite Mechanisms to Regulate Labour Relations}

The so-called tripartite mechanisms regulating labour relations refers to all the interactions and activities conducted by the government (usually represented by the labour department), employers and workers on the formulation and implementation of economic and social policies. ${ }^{3}$ It means that the government, employers' organization and trade union are working together through a certain organization and co-operation mechanism to resolve labour disputes. Article 19 of the $L D M A L$ stipulates that the labour dispute arbitration commission shall be composed of the labour administrative department, labor union representatives, and enterprise representatives. The establishment of tripartite mechanism in the labour dispute settlement is in line with the internationally accepted practice of dispute resolution. Furthermore, by implementing the "tripartite mechanism" into the labour dispute

\footnotetext{
${ }^{3}$ Tripartite Consultation (International Labour Standards) Convention, 1976 (No. 144).
} 
resolution: (i) parties in a labour dispute can be better guaranteed that the fairness and impartiality of the arbitration in that tripartite mechanism enhances the openness and transparency of the dispute settlement process; (ii) three parties can investigate the dispute and propose more solutions from their various distinctive perspectives;(iii) representatives of all parties have rights to voice and vote equally, and resolve conflicts through negotiation and consultation.

\section{Free Labour Arbitration}

Before the implementation of the $L D M A L$, the labour arbitration system charged a fixed fee billing for labour dispute cases. If an applicant did not pay an arbitration fee within the prescribed time limits, the application was revoked. However, in practice, a large number of labour dispute cases are related to migrant workers and urban low-income workers who have to give up on arbitration when the arbitration fee and other expenses are expected to exceed received compensation even if they win the arbitrations. Article 53 of the $L D M A L$ explicitly stipulates that labour dispute arbitration shall be free of charge and the outlay of labour dispute arbitration shall be guaranteed by the financial departments of the government. In this regard, the implementation of free labour dispute arbitration means that the labour arbitration system can genuinely provide services for the poor workers and the other ordinary people.

\section{(4) A Reasonable Time Limit for Labour Dispute Arbitration}

One of the major arbitration-related issues widely criticized in the past was that the timeframe in labour disputes arbitration was unreasonable. First, the time limits for filing a complaint was unreasonable. The old labour arbitration system required that an applicant submits a written application to labour dispute arbitration committee within 60 days from the date of occurrence of the labour dispute. In practice, the requirement resulted in a large number of applications being turned away by the arbitration organizations in that the applicant either were not aware of the infringement of rights or maliciously delayed and passed the time limitation of 60 days. Article 27 of the LDMAL modified the time limit of labor dispute application to one year, calculated from the date the parties knew or shall have known the infringement of their rights. This requirement, to a certain extent, eases the rush to collect evidence and apply for arbitration which was used to be constrained by the time limit.

Secondly, the arbitration process period used to be too long. In accordance with the previous provisions, the labour disputes arbitration committee shall accept the arbitration application within 7 days. The arbitral award shall be made within 60 days after receiving arbitration application (under special circumstances it can be extended to another 30 days). The $L D M A L$ shortens this time frame. Within 5 days of receiving the arbitration application, the labour dispute arbitration committee shall accept the case if it meets the conditions of acceptance. The labour dispute arbitration panel shall close the case within 45 days after accepting the arbitration application. In special circumstances and with the approval of the committee director, the proceeding can be extended by no more than 15 days. 
The new regulations, which stipulate the arbitral award must be made at most within 65 days after the committee receives the application, greatly shorten the arbitration process period.

\section{Quasi-Judicial and Quasi-Administrative Nature of Labour Dispute Arbitration}

The labour dispute arbitration system in China has quasi-administrative and quasijudicial characteristics. ${ }^{4}$ On the one hand, the office of the labor dispute arbitration committee is the affiliated agency within the labour administrative departments in the respective level. Also, the arbitration committee is composed of representatives of the labor administrative department in the government, trade union representatives, and the representatives from the comprehensive economic management departments of the government. All appointments, dismissals, and replacements of the arbitration committee members should be approved by human resources and social security organ of the government of the same level. Thus, arbitration institutions are of "administrative" nature. But on the other hand, labour arbitration in China possesses certain "quasi-judicial" characteristics. First, the arbitrator in a labour dispute is a neutral party to make an arbitral award based on the facts presented by the parties to the dispute. Secondly, the procedures applied and the legal effect of an award have some "judiciary" features. In particular, all decisions concerning applications, hearings and judging, are made according to the laws applied in the judicial procedures and can be legally enforced under certain conditions.

The dual natures of arbitration invite the administrative departments of the government to organize or participate in the labour dispute arbitration, detect problems in the mediation of labour relations timely, and develop policies to protect workers' interests by administrative powers. Such an intervention of the government can, on one hand, keep the balance of power between employers and employees, by making the strong party and weak party equal in the arbitration; and on the other hand, make too much dependence of arbitration on the administrative side which may weaken the independence of labour arbitration.

\section{The Defects in China's Labour Dispute Arbitration System}

\section{(1) The Labour Dispute Arbitration System Limits the Parties' Right to Appeal}

Chinese citizens have the right to request their government to safeguard their legitimate rights and interests, i.e. the subjects of civil legal relations are entitled to initiate litigation when there is a dispute on their rights and obligations or when their rights have been violated. An arbitration system, as a social dispute settlement mechanism, has judicial and administrative features. As a social remedy established in improving the deficiencies of public remedy, it should be applied on the premise of voluntary choice instead of a mandatory requirement.

4 Qin Guorong, "The Labour Dispute Resolution Mechanism Options: Critique of Pre-Placement of Arbitration Procedure in Labour Arbitration” (2011) Jianghai Academic Journal. 
However, China's labour dispute arbitration system uses the principle of "arbitration first and trial after," whereby the parties shall not initiate litigation without going through the arbitration process first. Also, if one party files an application for arbitration, the other party must respond, which essentially forces the party to participate in a non-voluntary arbitration, thereby violating their right to litigation. This mandatory requirement violates the free will of the parties and impedes the settlement of disputes. It is also very likely to increase the waste of judicial resources because parties would often initiate litigation for an unsatisfied arbitral award.

\section{The Administrative Feature of the Labour Dispute Arbitration System}

As mentioned earlier, the labour dispute arbitration system has a strong administrative feature. The labor arbitration committee is an internal organization within the labour administrative department. Under the tripartite system, the representatives from trade union and employers' enterprise as puppets often play no roles in the labour dispute arbitration, as in most cases it is difficult for them to represent the interests of employer and enterprise and thereby the labor administrative department is dominant in the arbitration. To make it worse, the director of the labour arbitration committee is often the same person of the head of labour administrative department of the same level, resulting in the inextricable link between arbitration process and executive power, which might cause the corruption in the arbitration and also make arbitration rewards dependent on administrative power.

\section{The Defects in The "One-Tier Arbitration and Two-Tiers Trials" Mechanism}

China's $L D M A L$ created the system of mandatory arbitration prior to litigation, with "final arbitration award" as an exception, and "one-tier arbitration and two-tiers trials" as general. In most cases, if the parties disagree with the arbitration award, they may initiate civil litigation in courts with two tiers trials. However, this mechanism tends to weaken the function of labour arbitration system as the remedy to decrease the cases docket in courts. Once the cases after arbitration flow into courts, all procedures conducted in the arbitration are nulled and the procedures in trial start again from the beginning, which at least takes 11 months to get the final outcome of the proceedings. Not only does the repeated work of arbitration and litigation waste judicial resources, but it also reduces the efficiency of courts and increases the costs of litigation. Although under certain conditions, certain labour disputes, are resolved by "finalizing some case with a single award" system, but there still exists unknowable factors in whether these cases can be actually finalized in practice.

Furthermore, arbitration and litigation have some inconsistency in terms of substantive law and procedure law application. Labour dispute arbitration organizations use a lot of administrative regulations and other regulatory documents issued by labour and social security departments. The People's Court, as an independent judiciary, applies laws, regulations and relevant judicial interpretations as the main legal rules, and takes department regulations only as a reference. In addition, as courts conduct trial proceeding accordance with the civil procedural law which has been practiced long in China, and is relatively well-established, and the labour dispute arbitration system has its own different procedure rules for the arbitration process, it causes overlapping, contradictions and confusions of procedure rules application when the case 
is transferred from arbitration to trial. For example, does the court accept the cases which have been declined by labour and personnel arbitration committee because of the jurisdiction reason? Does court have the power to review the arbitration rewards which have been final?

\section{(4) The Inadequate Oversight Mechanism for Labour Arbitration}

There is no justice without supervision. As the basic step in labour dispute resolution, labour dispute arbitration plays a prominent role in the arbitration system. At present, oversight for labour arbitration is limited to the cases where 1) arbitrator conducts bribery, favoritism, or abuse of process; 2) the arbitrator meets the parties or their representatives in private; 3) the arbitrator accepts the treat or gifts sent from the parties or their representatives. And as the penalty, it is simply that either the arbitration reward is dismissed, or the arbitrator is fired or born with the corresponding legal responsibility, ${ }^{5}$ which are not legally specified. Also, when the fault or illegal behavior of arbitration committee results in the loss of the party, the parties can neither initiate litigation against the arbitration committee nor appeal to any arbitration supervision bodies. The absence of the labour arbitration supervision mechanism, on the one hand, discharges the arbitrator from responsibility for their misconduct, which damages the authoritativeness of the arbitration system, on the other hand, undermines the liability of arbitration award, which results in arbitration going to litigation.

\section{Improving the Labour Arbitration System in China}

\section{(1) Arbitration or Litigation}

At present, it is argued that China's labour dispute resolution system should draw a strict line between arbitration and litigation: that is, the choice between arbitration and litigation should be typically conceived of as an either-or choice. Learning from the practical experience of western developed countries in labour arbitration system, "arbitration or litigation", the separation between arbitration and litigation, will be a tendency. Litigation, as a last resort to resolve social conflicts, is also the last phase in labour dispute settlement procedures. Litigation should play an authoritative role in supervising arbitration. Therefore, labour dispute arbitration system should be independent of the executive and the judicial proceedings, as a basic link in the settlement of labour disputes. "Arbitration or litigation" system will give parties options to better protect their rights, and will resolve the repetition of the similar proceeding in arbitration and trials, enabling arbitration or litigation settle the case within each system. It will conserve judicial resources as well as reduce litigation cycle and help both parties avoid high litigation costs.

\footnotetext{
${ }^{5} \mathrm{Yu}$ Chunyan, "The Defects and Improving of the Labour Arbitration System in China" (2007) The Legal System and the Society.
} 
The choice of arbitration or litigation, if more choices go to arbitration, will reduce the number of litigations in courts and devote more judicial resource to make high-quality decisions. However, in real life, people rely more on litigation proceedings because they think litigation is more authoritative and decisive. How can we make labour dispute arbitration become the first choice to solve the dispute? The following steps may be tried: First, to guide the parties to choose labour dispute arbitration procedures by free services and improved efficiency of arbitration; Second, to improve legal qualification of arbitrators, such as choosing arbitrators from excellent lawyers, or backbone judges specialized in labour law court etc.; Finally, to improve the authority and credibility of the arbitration award, such as the arbitration committee final award shall be irrevocable and so on.

\section{(2) Socialization of The Labour Arbitration System}

Based on the experiences of arbitration systems in other countries, the arbitration system China should be a dispute settlement mechanism in which the parties voluntarily choose a tripartite to solve the problems through negotiation on the equal and voluntary basis. Only in the cases where national interest or public interest is involved, the arbitration system needs to be enforced. Otherwise, the arbitration system should be a dispute resolution method selforganized, self-managed or self-coordinated by the public. Therefore, the labour arbitration system should be integrated into society by forming autonomous social organization voluntarily organizing, selecting, implementing by the public, which is more effective than implemented by authority.

The socialization of arbitration system needs to be done from two aspects. Firstly, while the current composition of the arbitration committee -the tripartite mechanism of arbitration system, is consistent with the requirements of socialization, the membership should be strictly divided among union representatives, business representatives and representatives of government departments. The representatives should be carefully chosen to represent the interests of the respective groups so that they could speak freely and work independently in arbitration consultation system. The arbitration committee shall be responsible for the selection and evaluation of arbitrators who should be chosen widely from various communities, especially lawyers, staffs in the enterprises, and social workers in the community. Meanwhile, to gradually reduce the excessive administrative intervention, and the abuse of administrative directives in replace of arbitration rewards, the labour administrative department should only provide policy support, and theoretical guidance in setting up and operation of the labour arbitration institution. Secondly, in terms of Arbitration Committee's independence, revision need to be made in the current provision that the chairman of Arbitration Committee shall be the head of local labour administrative department. The chairman of the Arbitration Committee shall be elected from the arbitrators, thereby enhancing the democratic nature and transparency of the arbitration institution. Furthermore, since the arbitration is free for the parties, the arbitration institution relies on the funding from the financial allocation of government, which is the source of the non-independence. Non-governmental organizations should be established in future to manage the arbitration funds, which comes from the government financial allocation and social donations, and 
thereby increase the inadequate funding and also monitor the behavior of the arbitration committee by a non-governmental organization.

\section{(3) Appropriate Linking of Arbitration and Litigation}

The appropriate linking of arbitration and litigation could be realized in two ways: first is the substantive law. As the arbitration organizations arbitrate mainly according to local regulations and labor administrative department rules while courts adjudicate according to laws and administrative regulations, which likely results in different law application, the legislative bodies need to unify legislation to make sure that the regulations applicable to the arbitration are consistent with laws. Secondly, from the procedural law point of view, the arbitration has its general procedure, with the exceptional application of civil law procedure. But as civil law procedure in China has a long-term practical experience and more wellestablished, the arbitration proceeding should not abandon the provisions in Civil Procedure Law and issue new regulations. The two independent procedures tend to confuse the parties in the arbitration.

To make an appropriate linkage between arbitration and litigation, the arbitration proceedings rule should be made by using civil litigation law or judicial interpretation as the reference, to shortened the litigation process and make arbitration parties understand the arbitration rules easily. For instance, in the "Interpretation (4) of the Supreme People's Court of Several Issues on the Application of Law in the Trial of Labour Dispute Cases" implemented in February 2013, article one states that: "When the labour and personnel dispute arbitration committee refuses to accept a labour dispute case on the ground that it has no jurisdiction over the case, and a party to the case files a lawsuit in the people's court, the people's court shall handle the case according to the following provisions: deeming that the labour and personnel dispute arbitration committee has no jurisdiction over the case upon examination, the people's court shall notify the party to apply for arbitration to the labour and personnel dispute arbitration committee having jurisdiction. Deeming that the labour and personnel dispute arbitration committee has jurisdiction over the case upon examination, the people's court shall notify the party to apply for arbitration and notify in writing the labour and personnel dispute arbitration committee of its examination opinion; and if the labour and personnel dispute arbitration committee still refuses to accept the case, and the party files a lawsuit for the labour dispute, the people's court shall accept the case."

The article fills the gap between the arbitration and litigation procedure, by making the cases accepted by the courts if the arbitration cases are not accepted by the labour and personal dispute arbitration committee that has the jurisdiction, or the cases that are not resolved only by arbitration.

\section{(4) Strengthening the Oversight Mechanisms for Labour Arbitration}

An effective labour arbitration system and independent oversight mechanism will be the future of the labour dispute resolution system. 
Firstly, the responsibility of the arbitrators and arbitration committee shall be clarified to improve the disciplinary rules for the misbehavior of the arbitrators and arbitration committee, as the responsibility is the basis for disciplinary. Secondly, there is a need to strengthen judicial oversight of labour arbitration. According to the pre-placement requirement, all labour dispute cases should go through arbitration before they can be dealt with through the court. If the court finds that the law was applied incorrectly, or if it identifies clear procedural errors or evidence of arbitrator's misconduct, the court may revoke the labour arbitration award. However, this is not courts' oversight of the arbitration organization, and the courts don't have the power to oversight the arbitration organization. Thus judicial oversight mechanism for labour arbitration should be established in order to supervise the behavior of the labour arbitration organizations. Finally, it is required to establish a diversified supervision mechanism. Learning from National Commercial Arbitration mechanism, a supervision system should be established including the supervisions of the labor administrative department, industry associations, labour unions, and public media. And the labor arbitration system will function well if the internal mechanism of democracy and supervision in Arbitration Committee is built, and the relation between litigation and arbitration is well balanced. 